\title{
Formulation Model of Power Based Technopreneurship in the Digital Technology Era
}

\author{
Elyta $^{\text {a }}{ }^{*}$, Martoyo $^{\text {a }}$, Herlan $^{\text {a }}$ \\ ${ }^{a}$ Faculty of Social and Political Sciences, Universitas Tanjungpura, Ayani Street, Pontianak, 78124, Indonesia \\ Corresponding author: *elyta@fisip.untan.ac.id
}

\begin{abstract}
The advancement of digital technology today has driven innovation in various aspects, including small and medium enterprises (SMEs) related to cybersecurity. The formulation of this problem is how to develop a manpower-based technopreneurship model by looking at the use of technology in empowering innovative resources. This research aims to analyze how to design a power-based technopreneurship formulation model in the era of digital technology. This research analyzed the literature using analytical techniques from journals and related news about energy-based technopreneurship in the digital technology era. This study indicates that power-based technopreneurship in small and medium enterprises is motivated to develop their business to take advantage of the times accompanied by advances in digital technology. This rebuilds the understanding of power-based technopreneurship in the era of digital technology to strengthen the business and potential of existing resources through technological updates that generate economic benefits. This condition shows a reference that contains considerations in the business environment in technological competition, especially in the international field. The results of this study indicate that there are three potential strength-based technopreneurship, namely thread starter, private message, transactions via virtual accounts (internet banking), delivery services, and "UKM Go Digital." The first challenge in strength-based technopreneurship is cybersecurity with solutions, namely mapping threats, strengthening laws, and maintaining good coordination between institutions. The second challenge is a global competition with solutions, creating innovations, adopting products by local companies, and making policies according to the government's competitive environment.
\end{abstract}

Keywords - Digital technology; technopreneurship; power.

Manuscript received 30 Jan. 2020; revised 25 Apr. 2021; accepted 21 Aug. 2021. Date of publication 31 Des. 2021. IJASEIT is licensed under a Creative Commons Attribution-Share Alike 4.0 International License.

\section{INTRODUCTION}

The development of political conditions in a developing country is measured by increasing government popularity, financial terms predictions, and predictions of interrelated conditions [1]. In the broader sense of the nation's political economy, it is essential to understand the policies of commodity value addition [2]. In this case, the political boom has a close relationship with the political economy's strength in a country that will bring significant human life changes. The digital technology era increasingly manifests significant human life changes, allegedly facilitating all human affairs and making something difficult or impossible to become a reality.

At present, technological literacy plays a vital role in the organization of government instruments [3]. Furthermore, this condition also influences each society's reflection and sociality, which has a centric personality. Consideration and sociality are intended to lead to the human mindset to develop strengths and efforts to expand relations and information between people, even if they do not meet directly. Some technology, communication, and information in internet media use a numerical system through various current methods [4]. One crucial element in technology is the internet that embodies the communication revolution. In realizing a process in communication, an orthonormal basis is needed.

Embodied Conversation Agent (ECA) is an application that conducts testing of mentorship sessions directly and provides benefits for users to understand better the system's performance and knowledge [5]. The conversation agency itself requires an internet network in its realization. Based on 2019 data from "We Are Social", the number of internet network users has grown at the rate of more than 11 new users per second, which results in a calculation of one million users per day. The Southeast Asian region recorded a total internet user presentation of 63 percent in January 2019 [6]. Indonesia is included as a country that exploits the internet's potential in 
following the flow of technological advancements, especially its influence on domestic income in the economic sphere [7][8].

Indonesia's gross domestic product income has increased in calculating the dollar exchange rate of $\$ 857$ in 2000. It is increased by $\$ 3,603$ in 2016, which made Indonesia a country with a relatively smooth economic movement, especially in the import sector and as a member of the G-20 international organization [9]. However, this increase has not released the Indonesian people from the poverty line; it is supported by the Asian Development Bank data about the Indonesian community still living below the poverty line of $10.6 \%$ in 2017 [10]. Also, about $97.64 \%$ of the Indonesian people choose to work in Malaysia, and the total number of people working abroad in 2015 is around 275 thousand [11]. Indonesia has many resources that can be used as employment. As we know, some countries in Asia have a high risk of disaster, one of which is Indonesia. This is due to Indonesia's geographical location, which is on the fire ring with many active volcanoes on tectonic plates [12]. Besides, Indonesia is endowed with many abundant natural resblonees.er, few Indonesian peoples are aware of the natural resources' potential, but the government seems to be moving independently to utilize natural resources. The wealth of natural resources and the high level of population in Indonesia have not synergized straightforwardly. The wealth of existing natural resources has not been utilized critically, especially those related to human resources. It has the impact that most Indonesians become workers, some in the country and some abroad, because they are oriented towards the benefits. They see the job that depends on a company as the only promising long-term job.

By recognizing these problems, the political apparatus is motivated to create a synergy to achieve national power by utilizing the digital technology potential by increasing the Indonesian economy to be a digital center throughout Southeast Asia [13]. At present, economic development brings innovative changes to the community, creating small and medium enterprises that require political support from the government [14]. Small and medium enterprises are believed to have an essential role in economic development in various countries, especially Indonesia, which simultaneously produces challenges and business confrualhtsand medium enterprises are considered less productive and integrated globally compared to large companies. Meanwhile, a business survey conducted by the International Trade Center shows that 17 percent of Indonesian companies have export activities owned by small and medium businesses [15].

This paper uses political analysis using the concept of power based on technopreneurship in the era of digital technology. These problems indicate no seriousness for small and medium businesses in managing and improving their capabilities. Based on this problem, it is necessary to apply research by developing a model for forming power-based technopreneurship as an innovation of small and medium enterprises in the digital technology era. It utilizes power in small and medium enterprises. Thus, this study aims to design a formulation model of power based technopreneurship in the age of digital technology.

\section{MATERIAL AND METHOD}

This research is applied research, aiming to do something better and more optimal in dealing with small and medium enterprises' problems in the technological era by using a power perspective. This research requires internal and external motivation to do it. Cause from within individuals is related to personal interest, comfort, and satisfaction from the reason itself. External factors that influence include the provision of awards and avoiding sanctions [16].

Research is a literature study by analyzing various journals and news related to power-based technopreneurship in the digital technological era. The results of different literature reviews will be used to identify the deconstruction of the understanding of power-based technopreneurship in the digital technology era and the potential for establishing power-based technopreneurship in the digital technology era. Data collection is done by collecting literature. After getting the data from the literature collection, data processing is carried out. Data processing aims to simplify data analysis. Data analysis techniques are used in descriptive research.

\section{RESULTS AND DISCUSSION}

\section{A. Deconstruction of Comprehension of Power-Based Technopreneurship in The Digital Technology Era}

The potential of technopreneurship is the ability of entrepreneurship by utilizing existing resources. For example, the community is currently in globalization and industrial development 4.0, causing the demand for mastery of soft expertise in technology in micro, small and medium enterprises., global markets, especially in developing countries [17]. Thus, small and medium enterprises become the power to form technology-based businesses or technopreneurship.

Although there are various changes realized by current technology, digital innovation will continue that cannot be ascertained [18]. The way to apply power-based technopreneurship can be done through education and training to provide skilled human resources [19]. This includes the commercialization of the school and the teaching system through internet social media [20]. In this case, indeed, education about social media is very much needed in the world of technopreneurship, given the increasingly digitizing era of digitization.

The current development, power-based technopreneurship can survive in the technology-based business sector. Various potentials in power-based technopreneurship refer to the readiness of multiple parties in Indonesia. The government and small and medium enterprises with technological innovations seek to realize the use of national resources.

A country can realize its purpose in prospering its people if it has two percent of entrepreneurial activities. In this case, the energy sector is an essential sector in entrepreneurship to realize improving welfare. In recent years, the renewable energy industry is increasing, including in Indonesia. This development is influenced by the increasing concern, government, private sector, and the community related to its use in various aspects of life [21]. In this case, to carry out activities in the economic sector is in dire need of entrepreneurial learning innovation. Along the times, entrepreneurial activities experienced innovation through 
technology-based entrepreneurship education. The emergence of technopreneurship is increasingly supported by strategic policies in improving the quality of resources that can strengthen entrepreneurship in competitive markets [22]. The transitional literature application supports Technopreneurship shows various dynamic entrepreneurs in post-socialist economics due to macro institutional reforms aimed at market formation [23]. Indeed, the emergence of this breakthrough is due to the efforts to maintain a business, considering that the current digital technology era is increasingly tightening competitiveness among business actors in the national scope and internationally. The expanded traffic of goods and knowledge is also the result of changing relations between the people and the country, leading to complicated conditions in the global business sector.

Competitive conditions in the business sector involve the role of the government. It was marked by allegations that showed the government's digitalization, which could generate more than one trillion dollars per year for the world. Based on globalization dynamics, the government's role can be seen through various countries' competitive values that launch investment, employment, knowledge, resources, and others [24]. In other words, changing entrepreneurship with the development of digital technology forces the government to contribute. Government support in self-innovation can support the state to survive and balance positions at the economic and political level with other countries.

In the context of intensive technology, technopreneurship can be a simple entrepreneurial process through technological abilities, talents, and entrepreneurial skills. It means that technopreneurship is the party that changes. The current developing economic system positively impacts product promotion to business institutions' organization and the empowerment of natural resources as raw material for trade [25]. Power is intended to develop based on logic to build the economy and influence a country's policies [26]. The power system structure is accompanied by market availability in generating competitive prices, independent transmissions, and unbounded power sectors.

Thus, technopreneurship is small and medium business actors who make innovations to develop entrepreneurship, while power can strengthen the economic sector. Based on this, researchers construct power-based technopreneurship, namely the ability to carry out a global revolution on the actions of technopreneurship that affect various aspects, especially on the economy's structure. It is seen through a breakthrough in innovation that strengthens the quality of goods and services to survive in the stock competition. The program is related to the management of the supply chain, which includes an integrated curriculum. The program runs sequentially from the planning, coordinating, and controlling stages of economic processes and practices. The principle used is the fulfillment of demand figures at the lowest possible price [27]. Of course, this activity requires technology to do so. The development of the digital technology era has influenced the synergy of business actors with the government that uses the potential of innovative resources and improves the quality of goods and services to market their products abroad through technology networks.
It cannot be denied that there is a close relationship between the needs of the global era and technology because the interaction of various parties can be done directly or indirectly using certain media, such as the internet.

In a broader scope, science and technology have a fundamental and meaningful influence on international affairs in every era. This condition is increasingly manifested by the impact of science and technology on foreign affairs. The real evidence is that globalization cannot be separated from the revolutionary process of information and communication technology. The linkages between science and technology with the global generally focus on internet governance to realize specific interests, such as Indonesia, to accomplish technopreneurship.

\section{B. Potentials in the Establishment of Power-Based Technopreneuship in the Digital Technology Era}

The business sector needs to make a breakthrough in adopting technological sophistication and capturing its potential globally. It has been proven that the era of digital technology brings challenges or obstacles. Still, the international community's massive potential will continue to experience growth in each age turn. The possibility that can be utilized is security through cyberspace, considering that information and communication technology are a significant technological development element. Based on reality, this condition can be implemented as an entrepreneurial innovation, namely power-based technopreneurship for people in each country, including Indonesia, namely thread starter, private message, transactions via virtual accounts (internet banking), and delivery service. More clearly, it can be stated various potential in establishing power-based technopreneurship in the digital technology era:

1) Thread Starter: Small and medium enterprises support a country's economic sector by opening employment opportunities [28]. In the era of digital innovation, this condition has driven consumer demand. It increased production requirements and digital services that the small and medium enterprise meets. In its implementation, various innovations refer to strengthening programs known in the exchange system in cyberspace by functioning to launch the promotion of power-based technopreneurship products to buyers online. In other words, this marketing strategy focuses on delivering communication messages or product intentions in marketing to attract consumers. Generally, the term abbreviated as TS is done by the business in online media. A business's success depends on communication effectiveness, especially in a multicultural and competitive global environment, impacting competitiveness. This is intended to promote marketing design, which certainly requires acceptable communication practices for local and international consumers [29]. This view is relevant to the potential for establishing power-based technopreneurship in foreign affairs because it creates an atmosphere that supports business potential through the development of communication at the marketing and communication level in various regions. Further analyzed, business people must join to become members of marketing spread in various Indonesia business sectors so that the products produced can access the market with broader coverage. Indeed, this requires communication to explain something or convey 
information excitingly and easily to understand the significant sentence in marketing the product. Moreover, communication in a broader range requires technological support that can be practiced through cyberspace. Marketing via cyberspace is an added value in promoting a product or service in the international.

This condition can also facilitate access to information that can bring new young entrepreneurs' creative ideas to enter power-based technopreneurship. A creative and innovative mindset means being able to produce new things that consumers need. Young people's role is very dominant in the business world because it is considered a fresher mindset or a trend. The honesty attitude that already exists in a young person will be beneficial in the business world. With the collaboration of talents and abilities in technology, various creative ideas that are realized can create and maintain consumers' trust, do not hesitate in the transaction, and buy power-based technopreneurship products while generating the potential that these consumers will become regular and loyal customers.

2) Private Message: Various business sectors that collaborate the internet with application systems can aim at supporting business processes and activities of international organizations, which are included as business actors. Forced business application systems refer to business resource planning, management interactions with consumers, supply chains, material requirements planning, human resources, including the business sector information system [18]. Also, the demand for micro-business services has increased to make it easier, independent, sustainable, and minimally risky [30]. This demand is, of course, highly influenced by technology upgrading.

Furthermore, the increase in technology globally that influences human life is now reflected in new advances in changing and analyzing information. Cybersecurity is needed to provide convenient services for each technology used to interact [16], which means that advances in technology and the emergence of machine networks have dramatically changed social interaction and produced society's progress for generations. This progress has necessary implications for the security aspect, considering that digital connectivity can look good to change the distribution of power and realize an interest. This potential refers to cybersecurity as a phenomenon that appears in both economic and political aspects.

In addition to TS services, technopreneurship potential reflects providing product ordering services that are quite practical and can include both internal departments and private companies abroad. Of course, product ordering services aim to establish communication via the internet between sellers and buyers to be more active without directly going to the seller's location. In this digital technology era, ordering services can be done through a private message (PM) or commonly known to chat. The PM is intended to facilitate business people with consumers in discussing products privately and more freely. Furthermore, this condition put the production in the modern era, which has brought online and offline concepts, where the idea of offline can be done by modeling pensions in certain stores or selling them in their stores. Whereas with the online theory, production results can be marketed through online shopping supported by internet networks. The method relates to purchases through social media such as Instagram and WhatsApp live camp chat applications to communicate with consumers (online) actively. In practice, this is relatively effective and efficient in forming power-based technopreneurship in current international. Marketing techniques via cyberspace, marketing activities of production also become sustainable even though it will cause friction or competition in every marketing, especially in creating the same type.

3) Transaction via Virtual Account (Internet Banking): If we talk about industry 4.0, we can describe it as a technological development phase. This phase is characterized by having creative and innovative processes in utilizing its technology [31]. This phase was the impact of the fourth industrial revolution that emerged widely through virtual space and was oriented towards smart technology [32]. Industry 4.0 is highly dependent on technological development.

By investing in money, ability, technology, or expertise, today's decision-makers can influence future decisions, as such investments impact the costs or benefits of future actions [33]. Today, technology has provided innovation in payment systems in the financial services industry. This condition is intended to reconstruct the financial industry's operations and an interactive forum between the parties concerned. Of course, in this process, the internet is needed as a medium to facilitate these activities. The internet is a network of computer networks connecting computing servers and computing clients across geographical boundaries worldwide. In its first 30 years, the Internet technology grew into the dominating cyber communication technology platform [34]. In this case, the internet network is undoubtedly closely related to the digital technology era.

Technology is an essential component of the revolution needed to push the microfinance bank system (MBS) efficiently and sustainably [35]. Today, of course, the technological aspects significantly affect all fields of human life and economic issues.

Based on several literature sources, it is known that the economy is developing lucratively, where developments take place with a higher degree of instability in developed countries. Whereas in developing countries, market and company competition conditions have not yet reached imperfections [34]. This condition positively affects economic aspects and disrupts financial stability. Of course, development processes need to occur if this happens. In building financial stability, a regular and safe operation is needed, so it is as to minimize damage to reputation in the future [36]. This reflects a discursive and centralized formation of supervision in observing money transactions [37]. Further identified, the idea is relevant to payment transactions' efficiency developed through a power-based technopreneurship system. There is confidence in the traditional financial management of small and medium enterprises that are considered irrelevant.

Problems related to the global crisis is mentioned implementing financial regulation policies that were considered weak [37]. This situation encouraged the political apparatus's reform process as a regulator and economic system [37]. In practice, it has continuity with the lack of 
attention to supervision in managing finances. Followed by the times and technology, the modified result of payment transaction services between power-based technopreneurship and consumers is increasingly made more accessible and very safe to use. Strategies for doing business are not entirely focused on the power of building customer relationships or linking consumer subjects. Still, new ideas in the form of mobile payments are also potentially considered [37]. This mobile payment means that transactions in the practice of internet networking and technology functions are vital elements in implementing power-based technopreneurship. Of course, this transaction leads to a registered business's bank, agency costs, and innovation capabilities. Technology-based bank innovation is believed to significantly influence the equity market because it can substantially reduce business performance [38]. The efficiency of payment transactions developed in the power-based technopreneurship system is supported by the traditional financial management of small and medium enterprises that have been irrelevant at this time. The situation reflected the lack of attention to supervision in managing business finance [39]. Thus, the modification of payment transaction services between power-based technopreneurship and consumers is increasingly comfortable and safe to use. Digital is a process of transferring internet-based alternative values such as PayPal, E-Gold, and other similar services that globally provide additional media for financial transactions. Thus, payment services from innovation based on power technopreneurship can facilitate and guarantee consumers in purchasing products while reaching out to customers outside the region and globally.

4) Delivery Service: The expansion of technopreneurship through delivery services helps develop a business [40], which means that product delivery services are also included as a vital element needed in utilizing the potential of power-based technopreneurship. The possibility of the internet network has provided delivery services effectively for the community, and the internet is an integral part of global political change.

Furthermore, this is a strategy designed based on marketing needs, especially for beginner businesses, which are generally carried out independently and attempt to promote products. The policy is a discourse on implementing business programs that will be marketed with ease of delivery to all regions. When power-based technopreneurship seeks to build its product brand, of course, it must think about the production capacity first. At the marketing level, this is not difficult to implement today, especially when sending products to consumers; delivery services are available. Informing a power-based technopreneurship business can attract customers because products are in demand by the market and can be easily purchased even though there are differences in business locations between power-based technopreneurship and consumers.

5) Small and Medium Enterprises (SMEs) Go Digital: Industrial 4.0 is the latest automation and data exchange

Fig. 1 illustrates that the consumption behavior of the trend in factory technology. The term encompasses cyber-physical systems, the internet for everything, cloud computing, and cognitive computing that have resulted in "smart factories." Industry 4.0 allows digitizing virtually internal sensing devices in all manufacturing components, products, and equipment. The ecosystem of industry 4.0 is surrounded by a large network of smart technologies connected to a global network, which makes the boundaries between the real world and virtual reality increasingly blurred and creates a phenomenon known as Cyber-Physical Production Systems (CPPS) [41].

This industrial 4.0 has caused massive changes in jobs and looking for income. Many that were previously done conventionally have now become online, including. This change is no exception experienced in this entrepreneurial sector, which helps humans to be able to carry out activities more quickly and easily. The emergence of technology provides many benefits for human survival. Its services make it easier for people to do all things so that it is faster and shorter, making users better. This progress can be seen in the telecommunications sector. The impact of advances in telecommunications is the exchange of information that becomes easy and fast and makes human relationships in terms of communication seamless and seamless. The internet is a communication network that connects people to share information and has many benefits. The public widely uses information technology for business in the form of online sales.

A survey conducted by the Indonesian Internet Service Providers Association showed that the number of internet users in Indonesia in 2018 had reached 171,17 million from 264,14 million people. The penetration of internet user growth in Indonesia is growing every year. The growth of internet users in Indonesia from year to year cannot be separated from many factors, significantly increasing telecommunications infrastructure development in cellular operators' regions and coverage. At the provincial level, the survey shows that in Java Island, West Java Province is the province with the highest internet penetration than Central Java and East Java. Its contribution is 6.6 percent. On the island of Sumatra, North Sumatra Province contributed 6.3 percent, the highest compared to other provinces.

On the island of Kalimantan, Indonesia shares a land border with Malaysia [42]. Meanwhile, West Kalimantan Province held the largest share with a contribution of 2.1 percent. Then, for Sulawesi-Maluku-Papua Island, South Sulawesi Province had the largest share, namely 3.7 percent [43]. The number of internet users in Indonesia can be seen in the following figure.

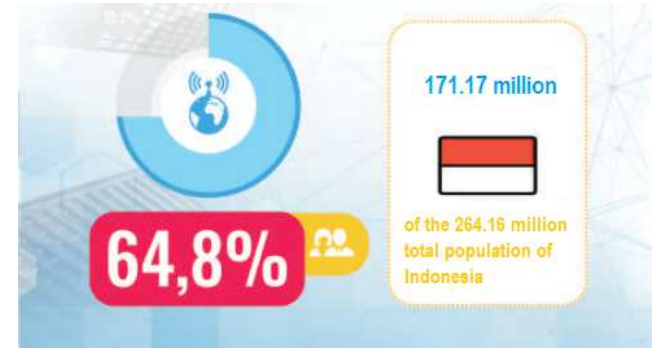

Fig. 1 Number of internet users in Indonesia [43]

Indonesian people is increasingly leading to a digital 
lifestyle. Marketing in today's world has shifted from conventional (offline) to digital (online). Online marketing is starting to be loved and considered more prospective because it can allow potential customers to obtain all kinds of information about products and transact via the internet. Furthermore, according to data reported by the United States digital marketing agency, We Are
Social, on internet users in Indonesia as of January 2019, the internet social media that is most widely used is YouTube. The next position was successfully filled by Instagram, Twitter, WhatsApp, Google, and other social media with a smaller percentage [44]. The data can be seen in the following Figure 2.

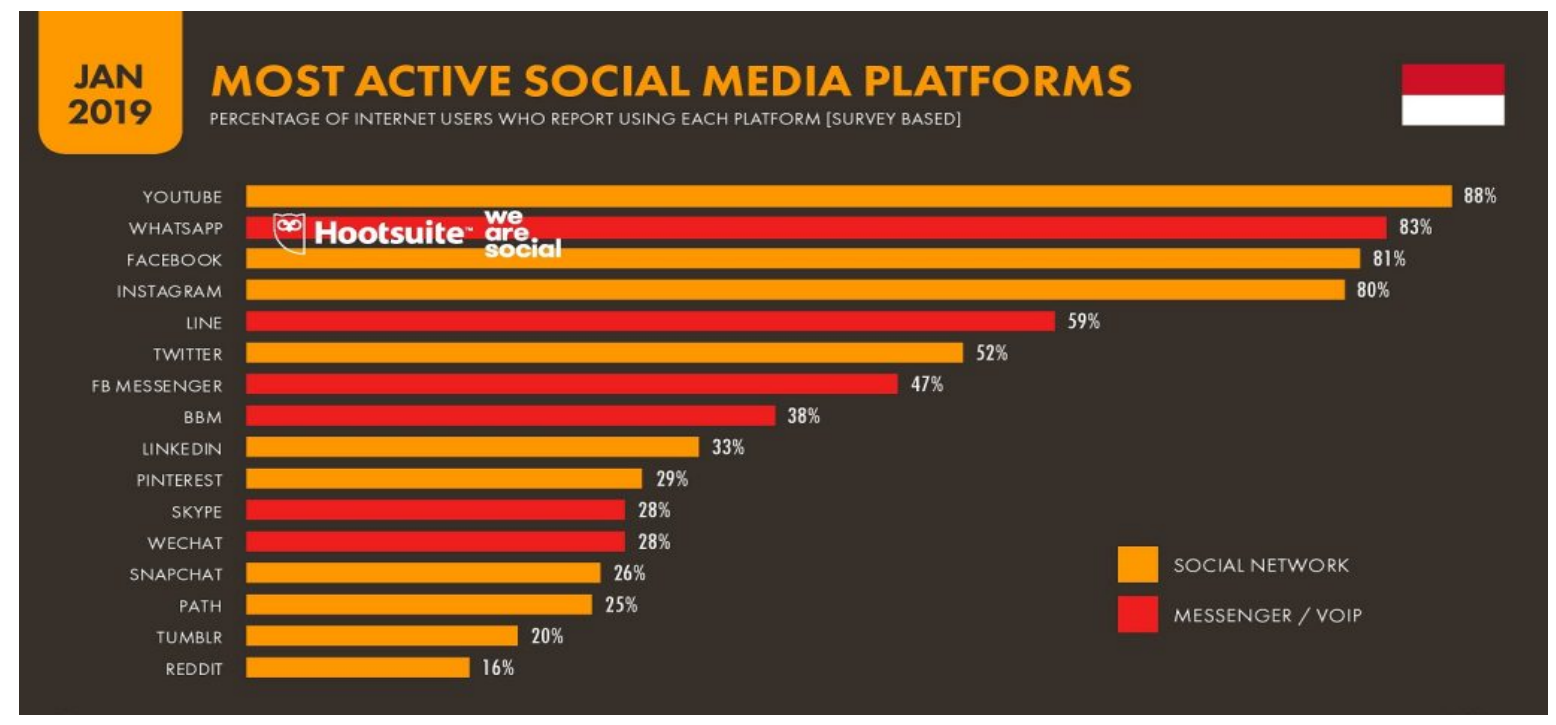

Fig. 2 Internet social media users in Indonesia (as of January 2019) [44]

Based on these two data, the Indonesian people are now familiar with using online media and using internet access. Its use is to seek information and, as a business, field to promote goods and enterprises so that many people can recognize them. This digital strategy's positive impact is that it can make it easier for potential customers to find out all kinds of information about the products they want to buy via the internet, often shopping through online media rather than face to face. There are already many, so to get a large market share and consumers, SMEs players should know and learn about the role of digital or sales through online media such as Facebook, Instagram, and others.

The Ministry of Cooperatives and Small and Medium Enterprises estimates that out of 64 million SMEs in Indonesia, only 13 percent have gone digital. The Ministry of Cooperatives and Small and Medium Enterprises targets 10 million SMEs to be digitized by the end of 2020 . There are currently 9.4 million SMEs that go digital, increasing by 1.4 million from 2019, which is still at 8 million SMEs [45]. Various business actors have exploited this potential to have a business perspective with digital marketing by utilizing digitalization to efficiently promote and sell their products to be recognized by the broader market. The development of more advanced technology is now believed to have helped SME operations more efficiently by changing time-consuming manual processes through digitization and automation. The hope is that this digital technology can help Indonesian SMEs be more effective and efficient in managing their business finances.

\section{Challenges in Establishing a Power-Based Technopreneuship in the Digital Technology Era}

Based on the perspective of liberalism, the free market or free market is influenced by financial innovation and credit deregulation, which creates opportunities to increase household loans [46]. Thus, the free-market era affects political and economic conditions in a country with adjustments that will be applied to compete and take advantage. Neither liberalization, economic globalization, nor the free market cannot be separated from trading activities. The three impacts on free up market access and information on a country's economy and affects trade activities in the free market ultimately create a new challenge for each country, namely global competition.

Historically, global competition has experienced an economic crisis and has generated momentum through investigations of moral and political status. This momentum leads to the market economy rules, investors' ethical principles, and ethical implications based on the economic model's assumptions. However, Coeckelbergh said that these investigations are less relevant in dissecting various allegations, thus encouraging more innovative ways by referring to technological aspects [47]. Further identified, this technical aspect is intended as financial technology or financial technology that functions to understand and evaluate economic practices that intersect with free markets.

The current phase of global innovation development is characterized as intense international competition in terms of technology, the quality of personnel considered satisfactory, and the growth of intensive investment in the knowledge sector. The results of this implementation showed the developments that developing countries have followed since the 21 st century. After that, the initial competition and competition stages were replaced in boasting an effect [48].

In connection with this phenomenon, the increasing global competition in the free-market era is inversely proportional to Indonesia's readiness, especially in the industrial sector, to increase exports. It is indicated that the industry's development and management need to be improved to prepare for competition in the free-market era. Another trigger refers to Indonesia's dependence on fuel imports of more than $65 \%$ [13]. As a country with a wealth 
of natural resources and local wisdom, Indonesia does not promise that the Indonesian industry will compete in the free market era by reducing imports to Indonesia.

Meanwhile, the local industry, which is a business activity in expanding employment opportunities, providing comprehensive economic services to the community, playing a role in the process of equalization, and increasing community income, encouraging economic growth, and playing a role in realizing national stability, also feels the constraints due to this impact. It is proven that external companies with giant technology finance have posed challenges and obstacles to other industries internally. This situation leads to external companies and emerging internal competitors or start-ups competing with each other to dominate the industrial market through innovative data access, brand strengthening, more efficient production operating costs, and the concept of a platform in doing business [49].

This condition reflects Indonesia's competitiveness, which seeks to keep up with innovations from other industrialized countries. Furthermore, Indonesia's existence in the free-market phenomenon is influenced by technological developments in supporting production and product access effectiveness. Of course, this leads to the implementation of financial technology, provision of funds, and infrastructure ready to compete with external industries.

The main obstacle in developing a competitive market is judged not due to anti-competitive behavior but also the lack of clear regulatory standards [50]. This regulatory standard can be identified through the political concept as a state authority in setting policies and providing solutions to society [51]. This study analyses the industrial sector to improve the competitiveness of Indonesian exports in the free-market era by measuring the competitiveness of Indonesian exports in the industrial sector through financial technology implementation, given the importance of the influence of technology during this period of globalization on the existence of industry as a support for the national economy.

The formation of power-based technopreneurship in the era of digital technology will undoubtedly be faced with various problems that are quite calculated, considering that business actors are increasingly competitive in maintaining their products both domestically and internationally. In this discussion, the researchers divided the challenges related to power-based technopreneurship as follows:

1) Cyber Security: The digital era is currently faced with various problems related to social interaction. Technological innovations are based on the disruption of interactive relationships between humans, followed by a technological paradigm known as computing. This concept reflects the fields of information and communication that have computer sensors [18]. It further touches critically on infrastructure security, privacy issues, international cooperation, and security policy. This has led to an analysis of the information revolution, which has an impact not only domestically but also globally. The infrastructure in question leads to a computer network accompanied by communication media.

Significant events recorded in the history of a country's progress cannot be separated from the community's social and political movements, which are informal. It is also not impossible to occur in Indonesia's political economy conditions in the current industrial revolution era 4.0 [52]. Today, the role of cybersecurity is increasingly vital for companies. The reason is, during the development of the 4.0 industrial revolution, which makes all electronic devices connected coupled with cloud computing technology and data supply, the role of cybersecurity seems to be non-negotiable. The security factor in the digital business itself has become a part of determining company safety. Many companies have gone out of business due to cyber-attacks. The world that is increasingly open to this technology needs to be watched out for, especially those who have a digital business. The rise of digital enterprises is sometimes used by those who want to get free money by hacking company websites and then asking for a ransom as profit. At the policy level, the handling of cybercrime is different from the handling of other crimes. In general, the government can easily control applicable laws within the country's sovereign territory [53].

In general, Indonesian people are familiar with politics and government. Due to the unfavorable economic situation, time is only used for routine activities related to their business to meet family needs. Currently, the trade entered into online media; then, cybersecurity is significant for corporate security [54]. Almost everyone will face problems in the current phenomenon when connecting their devices and systems via the internet [55]. No matter how small and big the business is, security is essential in the digital era. The security factor in the digital business itself has become a part of determining company safety. Many companies have gone out of business due to cyber-attacks. However, unfortunately, until now, there are still many companies and businesses in the country that do not understand the dangers of cybercrime, which at any time can threaten the company's existence.

Cybersecurity also has not received a significant priority in global economic, legal planning. The existence of legal regulations serves to ensure the ease of growth and operation of e-commerce. Therefore, a high cybersecurity level can ensure both producers' and consumers' security in the e-commerce trade to encourage digital business [56]. Cybersecurity has become a priority issue for all countries since information and communication technology is utilized in various aspects of life, both in social, economic, legal, organizational, health, education, culture, government, security, defense, and others.

Public Policy of In line with the high level of utilization of information and communication technology of global connectivity [57]. Cybersecurity risks are also increasing, driven by global connectivity and cloud services, such as Amazon Web Services, to store sensitive data and personal information. Not only that, but the pervasive low configuration of cloud service installations makes it easier for increasingly sophisticated cybercriminals to commit cybercrime, which means that entrepreneurs' risk from successful cyber-attacks or data breaches is increasing (vulnerable).

Current fact, no matter who the person is. Whether an individual, a small business, or a large multinational, will depend on computer systems every day. Pair this with increased cloud services, poor cloud service security, 
smartphones, and the Internet of Things (IoT) and have many cybersecurity threats that did not exist decades before. Therefore, we need to understand the difference between cybersecurity and information security, even though the skill sets are increasingly similar.

Further identified, these various problems have continuity with one another. If the security system in critical infrastructure is disrupted, this will significantly impact a country, seen through technology operations that will automatically stop functioning. It can be said that this vital infrastructure condition can be identified as an electronic attack or indirectly for privacy issues. It does not stop at that. This problem requires handling involving other countries in a cooperation forum such as the United Nations and its impact on the international sphere. This statement is supported by a view that believes international institutions are a path of stability in supervising and monitoring the virtual world domain [58].

Cybercriminals are becoming more sophisticated, changing their target, affecting organizations and their attack methods for different security systems. Social engineering remains the most accessible form of cyberattack with ransomware, phishing, and spyware as the most comfortable entry means. Third-party and fourth-party vendors who process data and have poor cybersecurity practices are other common attack vectors, making vendor risk management and third-party risk management even more critical.

Information theft is the most expensive and fastest-growing segment of cybercrime. Much of this is driven by the increasing exposure of identifying information to the web via cloud services. However, that is not the only target. Industrial controls that manage power grids and other infrastructure can be disrupted or destroyed. Moreover, identity theft is not the sole objective. Cyber-attacks may be aimed at compromising data integrity (destroying or altering data) to foster distrust of an organization or government. Of course, the challenges in information technology have a substantial impact on the global substance, which has referred to the emergence of technology piracy operations that hinder communication and public transportation networks in every country. This problem deals with the business power and political constraints faced by business actors [59]. It can be identified that virtual media in technopreneurship can be used according to business interests by emphasizing the practical side and affecting other competitors that allow a loss.

The solution to this cybersecurity challenge is first by mapping threats. As of January 2019, 56\% of Indonesia's around 150 million people use the internet. The number grew 13\% from the previous year. This growth is the fourth largest in the world after India, China, and the United States. Due to Indonesia's low cybersecurity system, the country is subject to frequent attacks. As an illustration, during one week in February, Indonesia received 1.35 million web attacks. These cyberattacks are mostly hacking cases, targeting government and corporate websites [60].

Global Cyber Security Index data released by the International Telecommunication Union (ITU) notes that Indonesia's cybersecurity is still ranked 70 out of 195 countries with a score of 0.424 . Therefore, support from all sectors is needed to build cybersecurity in Indonesia.
Indonesia's ranking has also risen to ninth position from the previously 16th position [61]. The data can be seen in the following figure.

\begin{tabular}{|l|c|c|c|}
\hline Member State & Score & Regional Rank & Global Rank \\
\hline Singapore & 0.898 & 1 & 6 \\
\hline Malaysia & 0.893 & 2 & 8 \\
\hline Australia & 0.890 & 3 & 10 \\
\hline Japan & 0.880 & 4 & 14 \\
\hline Republic of Korea & 0.873 & 5 & 15 \\
\hline China & 0.828 & 6 & 27 \\
\hline Thailand & 0.796 & 7 & 35 \\
\hline New Zealand & & 7 & 36 \\
\hline Indonesia & 0.789 & 8 & 41 \\
\hline India & 0.776 & 9 & 47 \\
\hline Viet Nam & 0.719 & 10 & 50 \\
\hline Philippines & 0.693 & 11 & 58 \\
\hline Iran & 0.643 & 12 & 60 \\
\hline
\end{tabular}

Fig. 32018 Global Cybersecurity Index [62]

The second solution that can be done to overcome cybersecurity problems is to strengthen the law. These cyber or cyber-attacks indicate that the government's existing cybersecurity system may not be effective. The current regulations related to cybersecurity are only the Law on Information and Electronic Transactions and the Government Regulation on the Implementation of Electronic Systems and Transactions. However, these laws and regulations do not cover interception handling in cyberspace or the management of trading via the internet. These regulations also do not regulate the government's role in cybersecurity systems, so that their use for cybersecurity is still limited. Therefore, the government needs to push for the passing of a draft cybersecurity bill in the House of Representatives to differentiate between handling attacks on cyber defense and cybercrime.

Besides, to establish good coordination between institutions. Likewise, with the urgency to develop safe digital infrastructure and industrial development. These three things are also essential solutions to tackling the challenges of cybercrime. The story of a digital security system can be started by updating cybersecurity technology to accommodate new cyber threats. The Indonesian cybersecurity industry is still developing. The market is still dominated by foreign hardware and software products. Only the local consulting services industry is thriving, providing services such as forensics and digital security. The government must coordinate with various agencies to create a road map for industrial development. Such goals require long-term research and planning supported by large capital.

2) Global Competition: Concerning economic capital, capital in the social aspect also supports a business's sustainability in the long term [63]. The emergence of challenges in power-based technopreneurship is based not only on other competitors but also on the business actors' personalities. This challenge arises when business actors have minimal knowledge of technology and information not to reduce promotional value.

The difference between people who have the knowledge and others who do not have the support of expertise will be 
evident. With experience, a person can form one's abilities, develop them, and strengthen one's mental self. In contrast, without knowledge, it will be easily shaken. So, a strong mentality is number one in business. Understanding the risks faced when deciding to enter the business world is very important by studying science. Besides, understanding related to resource empowerment with technology as an effective strategy in producing a product also affects business existence.

Furthermore, the challenge of establishing power-based technopreneurship from business actors is related to self-confidence issues. As a supporting medium in promoting product design, technology will provide feedback on market response. This determines the discontinuation or continuity of a business even though it gets competitive friction in every marketing. Based on the results of a survey conducted by the Indonesian Internet Service Providers Association in 2018, the following are the online market place that is mostly used by Indonesians seen that Shopee $(11,2 \%)$ is the most widely used trading platform for Indonesians, followed by Bukalapak $(8,4 \%)$ in second place and Lazada $(6,7 \%)$ in third place [43]. The market is not limited to specific location trends. Competition for influence in various external actors will profoundly impact all countries undergoing fundamental political change.

Furthermore, self-confidence starts with the first problem when starting a business because business capital is small, especially for a short-term company. A mentality that is not yet solid and enthusiasm that is still up and down causes concern to continue the industry. Still, building self-confidence is essential as a business foundation so that it continues to run. Capital continues the business with enthusiasm and understands the advantages and disadvantages of running a business. When experiencing ups and downs, business people will not lose concentration in managing their business.

Building self-confidence is not an easy thing; generally, this is motivated by insufficient knowledge of the material conveyed through communication. It is indicated that the message conveyed is not in line with the idea of thinking, so to overcome it can be done by building an atmosphere of excellent and relaxed communication. The next strategy is to communicate and deliver the goal by playing the atmosphere, such as opening the conversation with lightheartedness, greeting each other, and getting acquainted with gain the listener's trust (communicant). That way, the communication carried out will be conveyed appropriately and efficiently accepted.

After that, capital can be handled, and business people have built a strong mentality and enthusiasm. The problem also goes to another level, namely human resources. Human Resources are needed in running a business. Business actors cannot run it alone because the industry must develop automatically. The more a company grows, the broader the market, the more production increases, and the required expertise. The HR problem in question is a financial problem/funds as wages/salaries are given to workers.

Although currently, the workforce has limited contribution to the political economy, this condition is inversely proportional to the increasing number of human resources around the world. Various problems arise with multiple backgrounds, such as manipulating work contracts, recruitment fees, and others. [64]. These labour conditions have clouded the global atmosphere with signs of the emergence of illegal entry of labour.

However, in the international realm, these problems can be handled with technological sophistication. Some modern countries have dealt with labour problems by minimising factory labour and utilising machines to produce goods and provide services. However, there are indications of other issues that have arisen, namely an increase in the number of unemployed due to the limited job vacancies needed. This aspect has a significant impact on countries, especially developing countries like Indonesia, which has the third-largest population in the world.

The built competition is aimed at one business actor and another, but there are political interests involved. The global management system is closely related to changing situations that have adopted the transfer of technical knowledge. The development and dissemination of technological knowledge raise contestations between developed and developing countries by influencing policy objectives and provisions. These changes reflect competition between countries that have not fully explored various issue areas [65]. Based on the power perspective, the level of competitive behavior among entrepreneurs is determined by public market institutions' existence. It touches on the institutional and market motives owned by competitors [23].

The globalisation dimension, which includes the power approach, is proven to play a significant role in forming trade risk internationally [66]. Moreover, global climate change also coincides with a considerable effect on the business productivity system [40]. The clear evidence that this has occurred is the emergence of various speculations regarding the challenges related to power-based technopreneurship that have happened in the virtual world. This is proven by the competition for power-based technopreneurship that is built competitively in the global market. Every entrepreneur is competing with each other to improve product quality and attract customers. However, this competition becomes unhealthy when power-based technopreneurship players take advantage of technological sophistication in fraudulent ways to bring down business competitors, such as cyber-hacking, spreading hoax issues related to competing products.

The competitive global environment has shown knowledge and information to be a significant factor in strengthening competitiveness between countries. In reality, the policies implemented by each government as a determinant of the results of the competition have a direct impact on economic aspects [67]. In international affairs, this means that insight that follows the times is essential to surviving in a competitive business environment. The fact is that technology is currently a trend that needs to be mastered, resulting in comparisons between the ruling and weak states.

The use of technology-based on comparisons between developed and developing countries shows the level of digital intensity. Furthermore, this is also marked by digitization in the business sector supported by technology-based finance and asset density in the industrial sector. The real evidence is that Indonesia, as a developing 
country, often faces challenges based on the lack of adoption of the power of the internet in factories, customer appeal, and ineffective business processes. Social sectors, such as government and health services, are also a matter of digitization that reflects the global period [68]. In other words, competitive business competition in the international sphere demonstrates a concept that compares a country's capabilities and expertise in marketing products and providing services. This condition shows a variety of power-based technopreneurship that will compete tightly and increase barriers to entry of new or new power-based technopreneurship competitors.

Today's increased global competition has transformed the ecosystem that most entrepreneurs face today. In response to growing competitive pressures between local and foreign entrepreneurs, local companies were encouraged to improve performance by innovating and adopting process and product improvements. The solution to dealing with this global competition's challenges is government policies, including training that supports increased competition. The approaches made should be policies that promote equal employment globally and are suitable for a competitive environment [69]. Based on the result and discussions, the researcher maps the formulation model of power based technopreneurship in the era of digital technology, as in Figure 4.

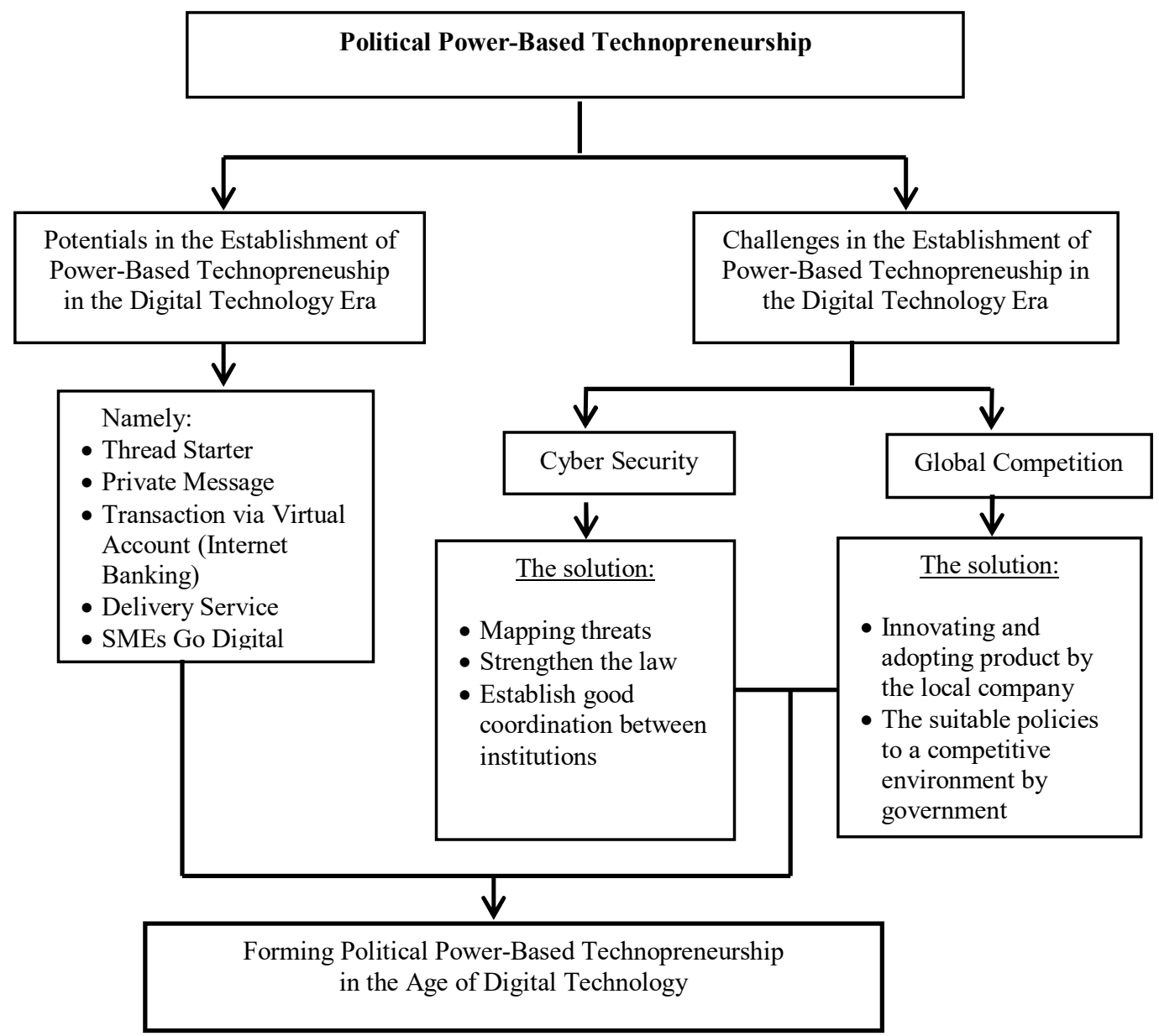

Fig. 4 Formulation Model of Power Based Technopreneurship in The Era of Digital Technology

\section{CONCLUSION}

Deconstruction of comprehension of the power-based technopreneurship in the digital technology era is a strengthening of business that empowers the potential of existing resources with technological renewal. In a broader understanding, resource recombination generates its profits and applies to a country's economic growth. This condition is a reference that considers a competitive business environment, especially in the global domain.

The potential in the construction of power-based technopreneurship in the digital technology era includes four parts. The first is a thread starter as a power-based technopreneurship marketing strategy that utilizes online media to attract consumers' interest in stock exchange practices. The second is a private message. It results from an internet combination and an application system that facilitates efficient interaction services between small and medium businesses with consumers. The third is transactions via virtual accounts, commonly known as internet banking, which is innovative technological ideas in the financial system to create the adequate performance of small and medium businesses and consumers via mobile transactions. The fourth is a delivery service vital for power-based technopreneurship because it plays a role in creating brand levels in demand by global markets. The last is SMEs Go Digital. The development of technology in today's digital era, which is very fast from day to day, has encouraged people not to be outdated and literate with technology. 
The challenges of forming power-based technopreneurship in the digital technology era will undoubtedly be faced with various problems that are quite calculated, considering that business actors are increasingly competitive in maintaining their products domestically and internationally. The challenges of power-based technopreneurship in the digital technology era are divided into three parts. The first is cybersecurity. The challenges in information technology have a significant impact on the global substance, which has referred to the emergence of technology piracy operations that hinder communication and public transportation networks in every country. The solution for this challenge is to map threats, strengthen the law, and establish good coordination between institutions.

The second is a global competition. The built competition is aimed at one business actor and another, but there are political interests involved. Moreover, the third is a personal mindset. This challenge arises when business actors have minimal knowledge of technology and information not to reduce promotional value. The solution for this challenge is creating innovating and adopting products by the local company and making suitable policies for the government's competitive environment.

\section{REFERENCES}

[1] H. Herrera, G. Ordoñez, and C. Trebesch, "Political booms, financial crises," J. Polit. Econ., vol. 128, no. 2, pp. 1-58, 2019, doi: 10.1086/704544.

[2] A. Lebdioui, "The political economy of moving up in global value chains: how Malaysia added value to its natural resources through industrial policy," Rev. Int. Polit. Econ., vol. 0, no. 0, pp. 1-34, 2020, doi: 10.1080/09692290.2020.1844271.

[3] M. Martoyo, E. Elyta, H. Herlan, and A. Arifin, "Economic Development and Sustainable Human Resources by Supply Chain Managament in Government Towards in West Kalimantan Indonesia," Int. J. Supply Chain Manag., vol. 9, no. 2, pp. $1054-1063,2020$

[4] J. Honda and T. Otsuyama, "Feasibility Study on Aircraft Positioning by Using ISDB-T Signal Delay," IEEE Antennas Wirel. Propag. Lett., vol. 15, pp. 1787-1790, 2016, doi: 10.1109/LAWP.2016.2536725.

[5] R. Kremers and J. Brassett, "Mobile Payments, Social Money: Everyday Politics of the Consumer Subject," New Polit. Econ., vol. 22, no. 6, pp. 645-660, 2017, doi: 10.1080/13563467.2017.1306503.

[6] Global Digital Report, "Digital 2019: Global Internet Use Accelerates - We Are Social," Web Site, no. January. pp. 1-20, 2019, [Online].

Available: https://wearesocial.com/blog/2019/01/digital-2019-global-internet-us e-accelerates.

[7] Martoyo and Elyta, "Model of Human Security-Based Policy of Business Increase Income Prosperous Family Indonesia," Rev. Int. Geogr. Educ. Online, vol. 11, no. 6, pp. 855-865, 2021, doi: 10.48047/rigeo.11.06.103

[8] Elyta, A. Razak, I. Rahman, Y. Fahruna, and F. D. Nailufar, "Model of Strengthening Economic Security Through the Implementation of Management Accounting for Small and Medium Business in Borders of States," Academy of Strategic Management Journal, vol. 20, no. 1. pp. 1-11, 2021.

[9] Worldbank.org, "Indonesia overview." 2018, [Online]. Available: https://www.worldbank.org/en/country/indonesia/overview.

[10] Adb.org, "Indonesian Poverty." 2018, [Online]. Available: https://www.adb.org/id/indonesia/poverty.

[11] Statista.com, "Indonesia Number of Indonesians Working Abroad by Country of Destination 2018 Statista." 2018.

[12] Z. F. Jailani, "Assessing indonesia spatial data infrastructure using $r$ for disaster management," Int. J. Adv. Sci. Eng. Inf. Technol., vol. 9, no. 6, pp. 1807-1812, 2019, doi: 10.18517/ijaseit.9.6.4173.

[13] The Jakarta Post, "Indonesia aims to be regional digital technology hub in 2020 - Business - The Jakarta Post," The Jakarta Post. 2019, [Online].

Available: https://www.thejakartapost.com/news/2019/02/20/indonesia-aims-tobe-regional-digital-technology-hub-in-2020.html.

[14] G. Ruchkina, M. Melnichuk, S. Frumina, and G. Mentel, "Small and medium enterprises in the context of regional development and innovations," J. Int. Stud., vol. 10, no. 4, pp. 259-271, 2017, doi: 10.14254/2071-8330.2017/10-4/20.

[15] A. González, "Empowering women, empowering the national economy," The Jakarta Post. 2016, [Online]. Available: http://www.thejakartapost.com/academia/2016/08/04/empowering-w omen-empowering-the-national-economy.html.

[16] D. I. Prihantony, Afrizal, R. A. Hadiguna, and T. Ophiyandri, "Construction industry ignorance to disaster risk reduction," Int. J. Adv. Sci. Eng. Inf. Technol., vol. 9, no. 6, pp. 1818-1824, 2019, doi: 10.18517/ijaseit.9.6.8176.

[17] J. Liu, M. Hu, H. Zhang, and J. Carrick, "Corruption and Entrepreneurship in Emerging Markets," Emerg. Mark. Financ. Trade, vol. 55, no. 5, pp. 1051-1068, 2019, doi: 10.1080/1540496X.2018.1531242.

[18] W. F. Cascio and R. Montealegre, "How Technology Is Changing Work and Organizations," Annu. Rev. Organ. Psychol. Organ. Behav., vol. 3, no. 1, pp. 349-375, 2016, doi: 10.1146/annurev-orgpsych-041015-062352.

[19] Elyta and D. Darmawan, "Education Politics: Learning Model Through Google Apps in Office Administration Management of Diploma Students," Cypriot J. Educ. Sci., vol. 16, no. 5, pp. 2152-2160, 2021, [Online]. Available: https://www.un-pub.eu/ojs/index.php/cjes/article/view/6235.

[20] S. Manca, "Snapping, pinning, liking or texting: Investigating social media in higher education beyond Facebook," Internet High. Educ., vol. 44, p. 100707, 2020, doi: 10.1016/j.iheduc.2019.100707.

[21] R. F. Mochamad and R. Preece, "Assessing the Impact of VSC-HVDC on the Interdependence of Power System Dynamic Performance in Uncertain Mixed AC/DC Systems," IEEE Trans. Power Syst., vol. 35, no. 1, pp. 63-74, 2020, doi: 10.1109/TPWRS.2019.2914318.

[22] Sumarno and Suarman, "Development of technopreneurship-based entrepreneurship education for students at Universitas Riau, Indonesia," Int. J. Econ. Res., vol. 14, no. 12, pp. 65-74, 2017.

[23] B. Pula, "What Makes Firms Competitive? States, Markets, and Organisational Embeddedness in Competitive Firm Restructuring in Postsocialist Economies," New Polit. Econ., vol. 23, no. 4, pp. 458-474, 2018, doi: 10.1080/13563467.2017.1371125.

[24] McKinsey\&Company, "Digital by default: A guide to transforming government," McKinsey Cent. Gov., no. November, p. 13, 2016.

[25] M. Selladurai, "Conceptual Framework on Technopreneurship," SELP J. Soc. Sci., vol. VII, no. 27, pp. 92-97, 2016.

[26] U. Heo and T. Roehrig, "Development Power Theory: The South Korean Case,” Pacific Focus, vol. 33, no. 1, pp. 111-140, 2018, doi: 10.1111/pafo.12107.

[27] K. F. Kodrat, S. Sinulingga, H. Napitupulu, and R. A. Hadiguna, "Supply chain performance measurement model of passion fruit agro-industry for sustainable micro, small, and medium enterprises with system dynamics in North Sumatra Province," Int. J. Adv. Sci. Eng. Inf. Technol., vol. 9, no. 6, pp. 1885-1891, 2019, doi: 10.18517/ijaseit.9.6.9076.

[28] T. World Bank, "Entrepreneurs and Small Businesses Spur Economic Growth and Create Jobs," Who We Are. pp. 1-4, 2016, [Online]. Available: http://www.worldbank.org/en/news/feature/2016/06/20/entrepreneurs -and-small-businesses-spur-economic-growth-and-create-jobs.

[29] U. Nwabueze and J. Mileski, "Achieving competitive advantage through effective communication in a global environment," $J$. Int Stud., vol. 11, no. 1, pp. 50-66, 2018, doi: 10.14254/2071-8330.2018/11-1/4.

[30] A. Akbulut and H. G. Perros, "Performance Analysis of Microservices Design Patterns," IEEE Internet Comput., vol. PP, no. c, p. 1, 2019, doi: 10.1109/MIC.2019.2951094.

[31] E. Elyta and A. Sahide, "Model of Creative Industry Management in Border Areas to Improve Bilateral Cooperation in Indonesia and Malaysia," Cogent Soc. Sci., vol. 7, no. 1, 2021, doi: 10.1080/23311886.2021.1974670.

[32] A. Muscio and A. Ciffolilli, "What drives the capacity to integrate Industry 4.0 technologies? Evidence from European R\&D projects," Econ. Innov. New Technol., vol. 0, no. 0, pp. 1-15, 2019, doi: 10.1080/10438599.2019.1597413.

[33] B. Harstad, "Technology and time inconsistency," J. Polit. Econ., vol. 128 , no. 7, pp. 2653-2689, 2020, doi: 10.1086/707024. 
[34] L. Liu, "Internet Technology Outlook," ACM Trans. Internet Technol., vol. 20, no. 1, pp. 1-4, 2020, doi: 10.1145/3378661.

[35] L. Uchenna Okoye, A. Ehimare Omankhanlen, A. Ahmed, F. N. Ezeji, and A. Ojo, "Technological Advances in Microfinance Banks and Economic Growth in Nigeria," Int. J. Civ. Eng. Technol., vol. 10, no. 3, pp. 60-71, 2019.

[36] H. Hungin and S. James, "Central Bank Reform and the Politics of Blame Avoidance in the UK," New Polit. Econ., vol. 24, no. 3, pp. 334-349, 2019, doi: 10.1080/13563467.2018.1446924.

[37] P. E. Dönmez and E. J. Zemandl, "Crisis of Capitalism and (De-)Politicisation of Monetary Policymaking: Reflections from Hungary and Turkey," New Polit. Econ., vol. 24, no. 1, pp. 125-143, 2019, doi: 10.1080/13563467.2017.1421624.

[38] Y. Zhu, "Banks' Governance and Innovation: Evidence from the Listed Firms in China," Emerg. Mark. Financ. Trade, vol. 55, no. 11, pp. 2409-2424, 2019, doi: 10.1080/1540496X.2018.1483229.

[39] T. Febby and A. J. Silubun, "Function of Village People's Representative Council in Financial Management of Village Poo," Int. J. Civ. Eng. Technol., vol. 10, no. 3, pp. 294-301, 2019.

[40] F. Zecca, "Article ID: IJCIET 1003050 Cite this Article: Francesco Zecca, The Use of Internet of Things for the Sustainability of the Agricultural Sector: The Case of Climate Smart Agriculture," Int. J. Civ. Eng. Technol., vol. 10, no. 03, pp. 494-501, 2019.

[41] S. I. Tay, T. C. Lee, N. Z. A. Hamid, and A. N. A. Ahmad, "An overview of industry 4.0: Definition, components, and government initiatives," J. Adv. Res. Dyn. Control Syst., vol. 10, no. 14, pp. 1379-1387, 2018.

[42] W. Kartikasari and Elyta, "West Kalimantan Border: How Tough Is it To Deal with the Covid-19 Pandemic?," Sociol. Y Tecnociencia, vol. 2, pp. 134-159, 2021, [Online]. Available: https://revistas.uva.es/index.php/sociotecno/article/view/5422.

[43] Asosiasi Penyelenggara Jasa Internet Indonesia, "Penetrasi \& Profil Perilaku Pengguna Internet Indonesia," Apjii, p. 51, 2019.

[44] B. S. P. Suyono, "Digital Marketing As an Integrated Marketing," Kompetensi, vol. 13, no. 2, pp. 121-151, 2019.

[45] P. Gumilar, "10 Juta UMKM Ditargetkan Go Digital, Startup Ini Tancap Gas," Bisnis.com, 2020.

[46] A. Offer, "Discussion Papers in Economic and Social History The Market Turn : From Social Democracy to Market Liberalism," 2016.

[47] W. Reijers, "Mark Coeckelbergh: Money machines: electronic financial technologies, distancing, and responsibility in global finance," Ethics Inf. Technol., vol. 17, no. 3, pp. 231-235, 2015, doi: 10.1007/s10676-015-9378-5.

[48] Н. Иванова and 3. Мамедьяров, "Наука И Инновации: Конкуренция Нарастает," vol. 23, pp. 47-56, 2019.

[49] I. P. F. Fin, "The Rise of Fintech - Foreword," SSRN Electron. J., no. 3, pp. 15-21, 2020, doi: 10.2139/ssrn.3565549.

[50] A. Fraile Carmona et al., "Competition issues in the Area of Financial Technology (FinTech) Policy Department for Economic, Scientific and Quality of Life Policies," Startmag.It, no. July, 2016.

[51] W. Widiastuti and M. A. Andrias, "Political Economic Policy Related to the Illegal Mini Market: Existence in Tasikmalaya City," Rev. Hist. Polit. Sci., vol. 5, no. 1, pp. 82-92, 2017, doi: 10.15640/rhps.v5n1a9.
[52] Elyta, Arifin, Y. Yohanes, and Martinus, "Political Movement on Non-State Actors to Realize The Entikong Border Community Welfare," J. Crit. Rev., vol. 7, no. 14, pp. 645-647, 2020.

[53] H. Ardiyanti, "Cyber-Security Dan Tantangan Pengembangannya Di Indonesia," pp. 95-110, 1986

[54] Elyta Elyta, H. Almuhtar, S. H. Azizurrahman, U. Nuzulian, and F. D. Nailufar, "The Types of the Sajingan Indonesia Border Society as Non-State Actor in Dealing with Global Challenges," Talent Dev. Excell., vol. 12, no. 2, pp. 4330-4340, 2020.

[55] P. Lošonczi, "Importance of Dealing with Cybersecurity Challenges and Cybercrime in the Senior Population," Secur. Dimens., vol. 26 , no. 26 , pp. 173-186, 2018, doi: 10.5604/01.3001.0012.7249.

[56] A. Pratamasari, "Cybersecurity and Custom Regulations as Trade Barriers in ASEAN e-Commerce: Case of Indonesian e-Commerce," J. Glob. Strateg., vol. 14, no. 1, p. 1, 2020, doi: 10.20473/jgs.14.1.2020.1-16.

[57] Elyta and Martoyo, "Public Policy and Indonesian Diplomacy for the Acceleration of International Goods Terminal Development," Proc. Int. Conf. Ind. Eng. Oper. Manag., pp. 2573-2582, 2021

[58] B. Valeriano and R. C. Maness, "International relations theory and cyber security: Threats, conflicts, and ethics in an emergent domain," in The Oxford Handbook of International Political Theory, no. June, 2018, pp. 259-272.

[59] T. Paster, "How Do Business Interest Groups Respond to Political Challenges? A Study of the Politics of German Employers," New Polit. Econ., vol. 23, no. 6, pp. 674-689, 2018, doi: $10.1080 / 13563467.2018 .1384453$

[60] Y. Pratomo, "APJII: Jumlah Pengguna Internet di Indonesia Tembus 171 Juta Jiwa," Kompas.com, 2019.

[61] I. Tempo, "indeks-keamanan-siber-indonesia-naik-29-tingkat," 2019.

[62] ITU, Global Cybersecurity Index 2018. 2019.

[63] D. O. Simatupang, M. Dawapa, R. Fachrizal, and U. Untari, "Social and economic capital on sustainability of sago processing business," Int. J. Civ. Eng. Technol., vol. 10, no. 3, pp. 273-281, 2019.

[64] G. LeBaron and N. Phillips, "States and the Political Economy of Unfree Labour," New Polit. Econ., vol. 24, no. 1, pp. 1-21, 2019, doi: 10.1080/13563467.2017.1420642.

[65] C. Oh, "Political Economy of International Policy on the Transfer of Environmentally Sound Technologies in Global Climate Change Regime," New Polit. Econ., vol. 24, no. 1, pp. 22-36, 2019, doi: 10.1080/13563467.2017.1417361

[66] F. Balli, F. M. Pericoli, and E. Pierucci, "Globalization and international risk-sharing: The role of social and political integration," Eur. J. Polit. Econ., vol. 55, no. December 2017, pp. 324-345, 2018, doi: 10.1016/j.ejpoleco.2017.12.006.

[67] Z. Wang, "Economic Competition, Policy Interdependence, and Labour Rights," New Polit. Econ., vol. 23, no. 6, pp. 656-673, 2018 , doi: 10.1080/13563467.2018.1384452.

[68] K. Das, M. Gryseels, P. Sudhir, and K. T. Tan, "Unlocking Indonesia's Digital Opportunity," McKinsey Co., no. October, pp. $1-28,2016$

[69] M. N. Baily et al., "Increasing global competition and labor productivity: lessons from the US automotive industry," McKinsy Glob. Inst., no. February 2005, pp. 1-146, 2005. 